\title{
Candidatus Cryptoplasma Associated with Green Lizards and Ixodes ricinus Ticks, Slovakia, 2004-2011
}

\author{
Božena Kočíková, Igor Majláth, \\ Bronislava Víchová, Lenka Maliničová, \\ Peter Pristaš, Vincent A. Connors, \\ Viktória Majláthová
}

During 2004-2011, we collected green lizards and Ixodes ricinus ticks in Slovak Karst National Park in Slovakia; $90 \%(36 / 40)$ of lizards and $37 \%$ of ticks removed from lizards were infected with family Anaplasmataceae bacteria. Only Candidatus Cryptoplasma sp. REP (reptile) was identified in these samples. Green lizards transmit this bacterium.

$\mathrm{T}$ he family Anaplasmataceae (Rickettsiales; Alphaproteobacteria) comprises bacteria that are able to invade and infect their vertebrate host's blood cells, bone marrow-derived phagocytic cells, and endothelial cells; these bacteria can also infect cells of insects, helminths, and arthropod reproductive tissues (1-3). Tickborne family members include bacteria of Anaplasma, Ehrlichia, Candidatus Neoehrlichia sp., and Candidatus Cryptoplasma californiense (4).

Although reptiles play a role as hosts for ixodid and argasid ticks, their role in maintaining tickborne Anaplasmataceae bacteria in the environment has not been described. Nieto et al. (5) suggested that lizards and snakes in the far western part of the United States could become exposed to Anaplasma phagocytophilum when fed on by infected ticks. Moreover, Rejmanek et al. detected 2 highly dissimilar strains of $A$. phagocytophilum in the same lizard species (6). In Europe, an undescribed Anaplasma sp. was detected in Ixodes ricinus ticks feeding on sand lizards and sand lizard blood samples $(7,8)$. In our study, we sought to confirm these previous findings by determining whether family Anaplasmataceae bacteria were present in lizards and their feeding ticks in Slovakia.

Author affiliations: Slovak Academy of Sciences, Košice, Slovakia (B. Kočíková, B. Víchová, P. Pristaš, V. Majláthová); Pavol Jozef Šafárik University in Košice, Košice (I. Majláth, L. Maliničová, P. Pristaš, V. Majláthová); University of South Carolina Upstate, Spartanburg, South Carolina, USA (V.A. Connors)

DOI: https://doi.org/10.3201/eid2412.161958

\section{The Study}

We conducted this study in the Slovak Karst National Park in Slovakia $\left(48^{\circ} 36^{\prime} \mathrm{N}, 20^{\circ} 52^{\prime} \mathrm{E}\right)$ during $2004-2011$. We carried out lizard capture and sample collections with official permits (6103/2007-2.1 and 5498/2011-2.2) issued by the Ministry of Environment of the Slovak Republic. We captured 103 green lizards (Lacerta viridis) and collected blood from 40 (30 males and 10 females). We collected 235 I. ricinus ticks (118 larvae and 117 nymphs) from 63 green lizards and 271 questing I. ricinus ticks (132 nymphs, 76 males, and 63 females) from the same area and immediately stored them in $70 \%$ ethanol.

We isolated DNA from lizard blood using a DNeasy Blood \& Tissue Kit (QIAGEN, Hilden Germany) and isolated DNA from ticks by alkaline hydrolysis. We performed PCR amplification in $25-\mu \mathrm{L}$ (total) reaction mixtures using the MasterTaq DNA Polymerase Kit (Eppendorf AG, Hamburg, Germany). We amplified sequences using the primer combinations EHR747 plus EHR521 or fD1 plus rP2 (9), which spanned almost the entire 16S rRNA sequence (Table 1 ). We examined the $\approx 250$-bp gene fragment of $16 \mathrm{~S}$ rRNA by single-strand conformation polymorphism (SSCP) analysis to determine Anaplasmataceae species type (10). We performed SSCP analysis following the protocol of Derdakova et al. (11). We ran positive control samples A. phagocytophilum, A. ovis, Wolbachia sp., and Candidatus $\mathrm{N}$. mikurensis with each reaction. We purified the PCR products obtained using the GenElute PCR Clean-Up Kit (Sigma-Aldrich, Buchs, Switzerland) and sequenced both strands. We edited variants obtained in this study (1,410 bp) using MEGA 4.0.2 (https://megasoftware.net/) and checked by eye. We made comparisons to sequences in GenBank with BLASTn 2.2.26 (https://pods.iplantcollaborative.org/wiki/display/DEapps/Blastn-2.2.26). For phylogenetic analysis of our variant (GenBank accession no. MG924904), we aligned 17 related sequences obtained from the GenBank database and constructed a phylogenetic tree using the Bayesian inference method (12).

We examined all blood and ticks collected for the presence of family Anaplasmataceae bacteria. Anaplasmataceae family members were present in 36 lizards (28 males and 8 females). Of the ticks removed from lizards, $87(37 \%)$ were infected, and of questing ticks, $18(6.6 \%)$ were infected (Table 2). 
Table 1. Primers used to amplify $16 \mathrm{~S}$ rRNA gene of Candidatus Cryptoplasma sp. found in green lizards and Ixodes ricinus ticks, Slovakia, 2004-2011

\begin{tabular}{|c|c|c|c|c|}
\hline Organism & $\begin{array}{c}\text { Primer } \\
\text { name }\end{array}$ & Sequences, $5^{\prime} \rightarrow 3^{\prime}$ & $\begin{array}{l}\text { Length of amplified } \\
\text { fragment, } b p\end{array}$ & Reference \\
\hline Family Anaplasmataceae & $\begin{array}{l}\text { EHR747 } \\
\text { EHR521 }\end{array}$ & $\begin{array}{c}\text { GCACTCATCGTTTACAGCGTG } \\
\text { TGTAGGCGGTTCGGTAAGTTAAAG }\end{array}$ & 247 & (10) \\
\hline Most eubacteria & $\begin{array}{l}\mathrm{fD} 1 \\
\mathrm{rP} 2\end{array}$ & $\begin{array}{l}\text { CCGAATTCGTCGACAACAGAGTTTGATCCTGGCTCAG } \\
\text { CCCGGGATCCAAGCTTACGGCTACCTTGTTACGACTT }\end{array}$ & 1,500 & (9) \\
\hline
\end{tabular}

Denatured and electrophoresed PCR products from samples demonstrated several SSCP profiles, of which 1 was clearly distinguishable from the profiles of the Anaplasmataceae species used as controls (Figure 1). We detected this unique profile in all lizard blood samples, all ticks feeding on lizards, and some questing ticks. We sequenced representatives of this unidentified SSCP profile $(\approx 247 \mathrm{bp}$; GenBank accession nos. KY031322-3) and compared them with DNA fragments in the GenBank database. The closest related (99\% identity) 16S rRNA sequences were from uncultured Anaplasma sp. isolates from questing I. ricinus ticks from Morocco (GenBank accession no. AY672415), Tunisia (GenBank accession no. AY672420), and France (GenBank accession no. GU734325). Sequencing of a longer $(1,410-\mathrm{bp})$ fragment of the 16S rRNA gene revealed $99.1 \%$ similarity with the Candidatus $\mathrm{C}$. californiense isolate from I. pacificus ticks in California (Figure 2). The 16S rRNA sequence obtained in this study was found to share a maximum of $94 \%$ identity with $A$. phagocytophilum Norway variant 2 (GenBank accession no. CP015376). The phylogenetic tree we constructed using 16S rRNA gene sequences showed that the reptile-associated Candidatus Cryptoplasma sp. REP (reptile) clustered in a separate branch with Candidatus $\mathrm{C}$. californiense, indicating the isolate represents a lineage distinct from other known Anaplasmataceae species (e.g., A. phagocytophilum, A. marginale, A. platys, Ehrlichia muris, E. chaffeensis, and E. ewingii).

\section{Conclusions}

The role of ectotherm animals, especially lizards, in the maintenance of vectorborne pathogens is not clear. The interaction between reptiles and Anaplasmataceae family members has only been investigated in a few studies. Our findings expand knowledge on this research topic. Only limited information about the reptile-Anaplasma relationship exists. Ekner et al. suggested that sand lizards could potentially serve as a reservoir host for species of the Anaplasmataceae family when she discovered that ticks collected from these lizards in Poland were infected with Anaplasma-like pathogens (8). Although A. phagocytophilum might be transmitted by reptiles to a limited extent (5), the Anaplasma-like species detected in reptiles could also be a novel species, as suggested by Rejmanek et al. (6).

Despite the fact that lizards are exposed to a number of family Anaplasmataceae bacteria through infected ticks, our findings suggest that, except for Canditatus Cryptoplasma sp. REP, green lizards do not acquire infections with these species. In short, we detected Canditatus Cryptoplasma sp. REP in $90 \%$ of examined lizards, $37 \%$ of ticks feeding on lizards, and $6.6 \%$ of questing ticks in localities with lizards.

On the basis of our results, we cautiously speculate that Canditatus Cryptoplasma sp. REP is selected for and other genospecies selected against in ticks feeding on lizards. The Canditatus Cryptoplasma sp. REP variant had a high homology $(100 \%)$ with a sequence obtained from an Apodemus agrarius mouse from Slovakia (13), which indicates that rodents or other mammals might also become infected with this bacterium and contribute (to a lesser extent) to the circulation of these bacteria in nature.

In conclusion, we found a yet to be named species of Canditatus Cryptoplasma sp. (Canditatus Cryptoplasma sp.

\begin{tabular}{|c|c|c|c|c|c|c|}
\hline \multirow[b]{2}{*}{ Tick source, type } & \multirow[b]{2}{*}{$\begin{array}{l}\text { No. ticks } \\
\text { examined }\end{array}$} & \multirow[b]{2}{*}{$\begin{array}{c}\text { No. }(\%) \text { positive } \\
\text { ticks }\end{array}$} & \multicolumn{4}{|c|}{ No. (\%) positive ticks } \\
\hline & & & $\begin{array}{c}\text { Candidatus } \\
\text { Cryptoplasma }\end{array}$ & $\begin{array}{c}\text { Anaplasma } \\
\text { phagocytophilum }\end{array}$ & $\begin{array}{l}\text { Wolbachia } \\
\text { pipientis }\end{array}$ & $\begin{array}{c}\text { Candidatus } \\
\text { Neoehrlichia mikurensis }\end{array}$ \\
\hline \multicolumn{7}{|l|}{ Lizards } \\
\hline Larvae & 118 & $43(36.4)$ & $43(100)$ & - & - & - \\
\hline Nymphs & 117 & $44(37.6)$ & $44(100)$ & - & - & - \\
\hline Total & 235 & $87(37)$ & $87(100)$ & - & - & - \\
\hline \multicolumn{7}{|l|}{ Vegetation } \\
\hline Nymphs & 132 & $8(6.1)$ & 2 & 3 & 3 & 0 \\
\hline Males & 76 & $4(5.3)$ & 1 & 2 & 0 & 1 \\
\hline Females & 63 & $6(9.5)$ & 3 & 2 & 1 & 0 \\
\hline Adults & 139 & $10(7.2)$ & 4 & 4 & 1 & 1 \\
\hline Total & 271 & $18(6.6)$ & 6 & 7 & 4 & 1 \\
\hline
\end{tabular}




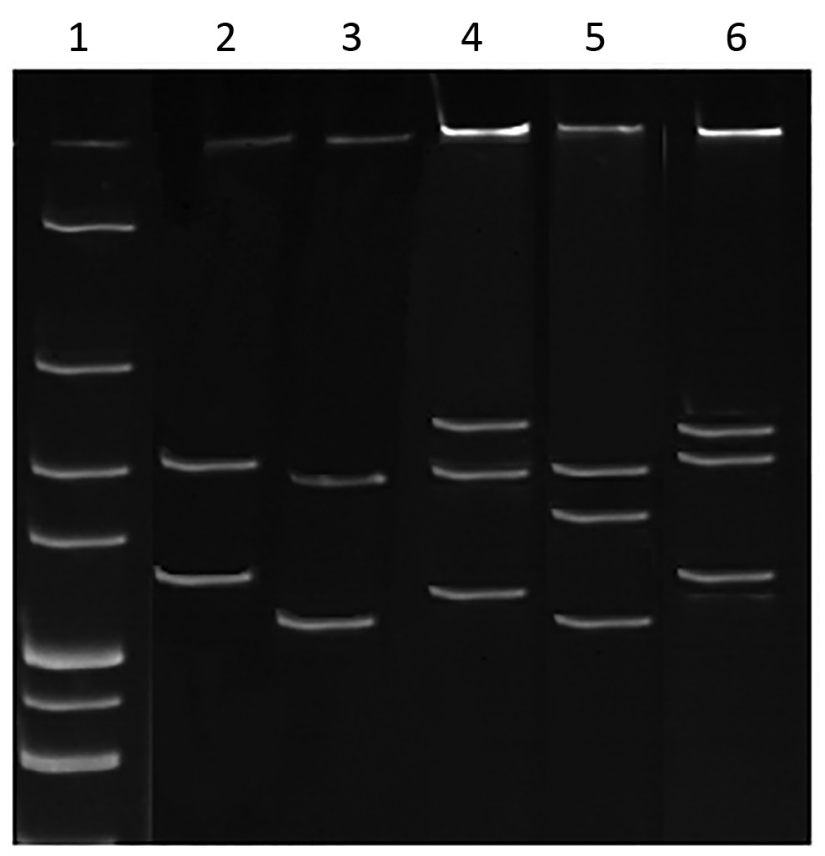

Figure 1. Single-strand conformation polymorphism profile of Anaplasmataceae isolate from reptiles, Slovakia, 20042011. The 247-bp 16S rRNA PCR fragments from the isolate from reptiles and known Anaplasmataceae species were denatured and electrophoresed. Lane 1, 100-bp ladder marker; lane 2, Candidatus Neoehrlichia mikurensis; lane 3, Anaplasma phagocytophilum; lane 4, isolate Candidatus Cryptoplasma sp. REP (reptile) obtained in this study; lane 5, A. ovis; and lane 6, Wolbachia.
REP) in questing I. ricinus ticks, I. ricinus ticks collected from and feeding on green lizards, and the blood of green lizards in Slovakia. These results indicate that green lizards serve as an intermediate host for this bacterium and that lizards can influence the enzootic maintenance and circulation of bacteria in the environment. However, other hosts besides reptiles could be involved in the Canditatus Cryptoplasma sp. REP lifecycle as well, though probably to a lesser extent.

This study was conducted within the framework of the project Environmental Protection against Parasitozoonoses under the Influence of Global Climate and Social Changes (project no. 26220220116), which is supported by the Research and Development Operating Program funded by the European Fund for Regional Development (0.4). Additional support was provided by the Scientific Grant Agency of the Ministry of Education of the Slovak Republic, Slovak Academy of Sciences VEGA 2/0113/18 (to I.M.), and EurNegVec COST Action TD1303. We thank the Fulbright Foundation (USA, to V.A.C.) for support.

\section{About the Author}

Dr. Kočíková is a postdoctoral researcher at the Department of Vector-Borne Diseases, Institute of Parasitology, Slovak Academy of Sciences, Košice, Slovakia. Her research interests include ecology and epidemiology of ticks and tickborne pathogens, the role of reptiles in transmission of vectorborne microorganisms, and molecular diversity of emerging parasitic and infectious disease agents in light of global changes.

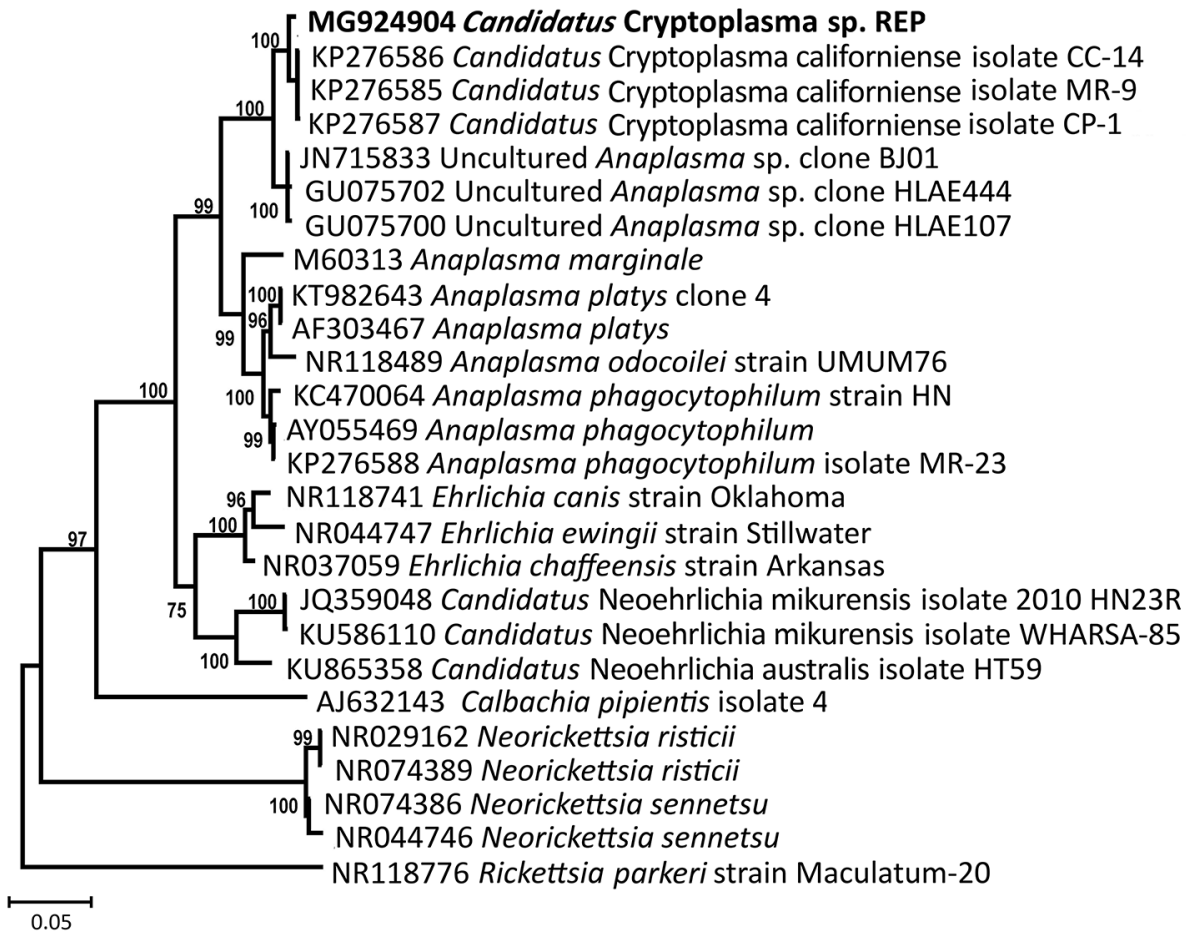

Figure 2. Phylogenetic relatedness of Candidatus Cryptoplasma sp. REP (reptile; bold), Slovakia, 2004-2011, to other Anaplasmataceae sp. family members. We constructed the tree using 16S rRNA sequences and the Bayesian inference method. The Rickettsia parkeri sequence was used as an outgroup. Scale bar indicates nucleotide substitutions per site. 


\section{References}

1. Dumler JS. Anaplasma and Ehrlichia infection. Ann N Y Acad Sci. 2005;1063:361-73. http://dx.doi.org/10.1196/ annals.1355.069

2. Rikihisa Y. Mechanisms to create a safe haven by members of the family Anaplasmataceae. Ann N Y Acad Sci. 2003;990:548-55. http://dx.doi.org/10.1111/j.1749-6632.2003. tb07425.x

3. Rar V, Golovljova I. Anaplasma, Ehrlichia, and "Candidatus Neoehrlichia" bacteria: pathogenicity, biodiversity, and molecular genetic characteristics, a review. Infect Genet Evol. 2011;11:1842-61. http://dx.doi.org/10.1016/ j.meegid.2011.09.019

4. Eshoo MW, Carolan HE, Massire C, Chou DM, Crowder CD, Rounds MA, et al. Survey of Ixodes pacificus ticks in California reveals a diversity of microorganisms and a novel and widespread Anaplasmataceae species. PLoS One. 2015;10:e0135828. http://dx.doi.org/10.1371/ journal.pone. 0135828

5. Nieto NC, Foley JE, Bettaso J, Lane RS. Reptile infection with Anaplasma phagocytophilum, the causative agent of granulocytic anaplasmosis. J Parasitol. 2009;95:1165-70. http://dx.doi.org/10.1645/GE-1983.1

6. Rejmanek D, Bradburd G, Foley J. Molecular characterization reveals distinct genospecies of Anaplasma phagocytophilum from diverse North American hosts. J Med Microbiol. 2012;61:204-12. http://dx.doi.org/10.1099/jmm.0.034702-0

7. Tijsse-Klasen E, Fonville M, Reimerink JHJ, Spitzen-van der Sluijs A, Sprong H. Role of sand lizards in the ecology of Lyme and other tick-borne diseases in the Netherlands. Parasit Vectors. 2010;3:42. http://dx.doi.org/10.1186/ 1756-3305-3-42

8. Ekner A, Dudek K, Sajkowska Z, Majláthová V, Majláth I, Tryjanowski P. Anaplasmataceae and Borrelia burgdorferi sensu lato in the sand lizard Lacerta agilis and co-infection of these bacteria in hosted Ixodes ricinus ticks. Parasit Vectors. 2011;4:182. http://dx.doi.org/10.1186/1756-3305-4-182

9. Weisburg WG, Barns SM, Pelletier DA, Lane DJ. 16S ribosomal DNA amplification for phylogenetic study. J Bacteriol. 1991;173:697-703. http://dx.doi.org/10.1128/ jb.173.2.697-703.1991

10. Pancholi P, Kolbert CP, Mitchell PD, Reed KD Jr, Dumler JS, Bakken JS, et al. Ixodes dammini as a potential vector of human granulocytic ehrlichiosis. J Infect Dis. 1995;172:1007-12. http://dx.doi.org/10.1093/infdis/172.4.1007

11. Derdáková M, Beati L, Pet'ko B, Stanko M, Fish D. Genetic variability within Borrelia burgdorferi sensu lato genospecies established by PCR-single-strand conformation polymorphism analysis of the $r r f A$-rrlB intergenic spacer in Ixodes ricinus ticks from the Czech Republic. Appl Environ Microbiol. 2003;69:509-16. http://dx.doi.org/10.1128/AEM.69.1.509516.2003

12. Tamura K, Stecher G, Peterson D, Filipski A, Kumar S. MEGA6: Molecular Evolutionary Genetics Analysis version 6.0 Mol Biol Evol. 2013;30:2725-9. http://dx.doi.org/10.1093/ molbev/mst197

13. Štefančíková $A$, Derdáková $M$, Lenčáková $D$, Ivanová $R$, Stanko M, Čisláková L, et al. Serological and molecular detection of Borrelia burgdorferi sensu lato and Anaplasmataceae in rodents. Folia Microbiol (Praha). 2008;53:493-9. http://dx.doi.org/10.1007/s12223-008-0077-z

Address for correspondence: Viktória Majláthová, Institute of Parasitology, Slovak Academy of Sciences, Hlinkova 3, 04001 Košice, Slovakia; email: majlat@saske.sk

\section{EID SPOTLIGHT TOPIC}

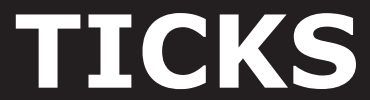

Ticks transmit a variety of different pathogens, including bacteria, protozoa, and viruses, which can produce serious and even fatal disease in humans and animals. Tens of thousands of cases of tickborne disease are reported each year, including Lyme disease.

Lyme disease is the most well-known tickborne disease. However, other tickborne illnesses such as Rocky Mountain spotted fever, tularemia, babesiosis, and ehrlichiosis also contribute to severe morbidity and more mortality each year.

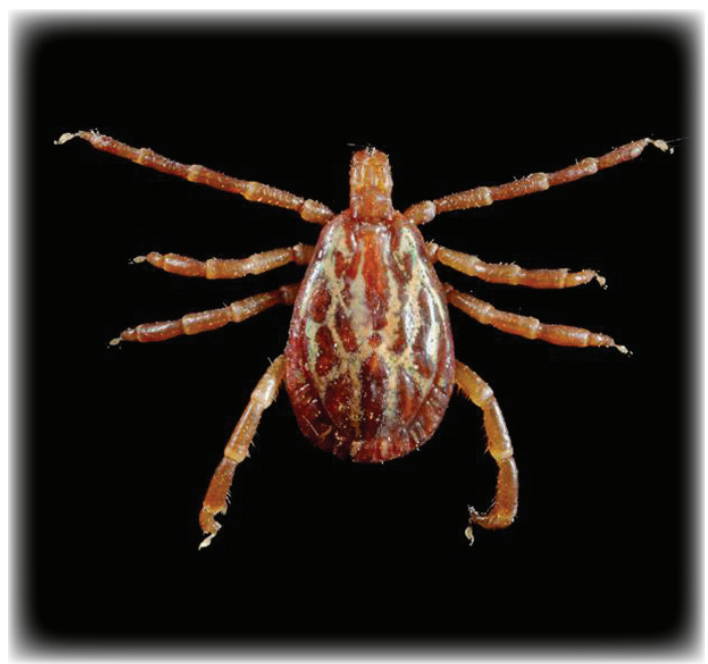

https://wwwnc.cdc.gov/eid/ page/tick-spotlight

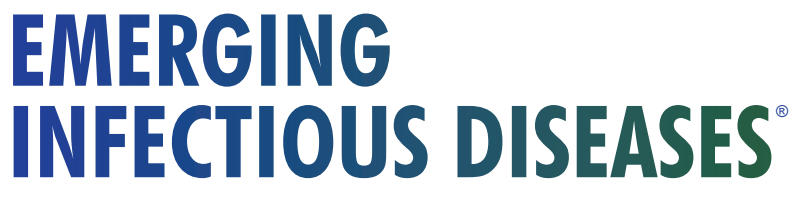

